\title{
GENERÁCIÓK, TÁRSADALMI CSOPORTOK A 21. SZÁZADBAN
}

\section{GENERATIONS, SOCIAL GROUPS IN THE 21 ${ }^{\text {ST }}$ CENTURY}

\author{
Buda András \\ egyetemi adjunktus, Debreceni Egyetem Nevelés- és Múvelődéstudományi Intézet \\ buda.andras@arts.unideb.hu
}

\begin{abstract}
ÖSSZEFOGLALÁS
A különböző generációs elméletek meglehetősen népszerűek a társadalomkutatók körében, sokféle elemzéshez jelentenek kiindulópontot. Az már más kérdés, hogy mennyire összevethetők ezek egymással, hiszen a közös (történelmi) események (például a II. világháború) megélése nemzetenként jelentősen eltérő lehet. Az utóbbi néhány évtized digitális technikai változásai, újdonságai azonban olyan összetett hatásrendszert generáltak, mely nagyon hasonlóan hat az egyes országok polgáraira. Az internet következtében a világ bármely pontján ugyanazokat az eseményeket, folyamatokat követhetik nyomon a felhasználók, azonos hatások, trendek érvényesülnek, új típusú, globális generáció jött létre. Természetesen napvilágot láttak olyan kategorizálások is, melyek az egyes csoportok digitális világhoz történő viszonyulásán alapulnak, ezek közül Marc Prensky nagyon leegyszerűsített, kétpólusú felosztása a legismertebb. Sokan még most is ezt a félrevezető besorolást tekintik alapnak, érdemes ezért bepillantani a valós helyzetet pontosabban leíró, aktuális elméletekbe.
\end{abstract}

\begin{abstract}
Various generation theories are rather popular among social researchers, and yield a point of departure for many different analyses. Whether they are compatible with one another is another question, as experiencing the same (historical) events (e.g. WWII) can be different from nation to nation. The changes and innovations in digital technology of the past couple of decades, however, have generated a complex system of effects which influence the citizens of individual countries in a very similar way. Owing to general access to the Internet the same events and processes can be followed by users in any corner of the world, the same impacts and trends are observed, and a new type of global generation has come into existence. Naturally, there are some methods of classification, too, which are based on the relationship of different groups to the digital world, including the most famous one, an extremely simplified, binary division by Marc Prensky. Many researchers still regard this misleading theory as the basis of their work, therefore, it is worth taking a glance at current theories, which describe the situation in a more precise way.
\end{abstract}

Kulcsszavak: társadalmi csoportok, generációk, digitális generációk

Keywords: social groups, generations, digital generations 
A társadalom különböző életkorú csoportjai között alapvetően fennállnak bizonyos különbségek, hiszen a csoportok tagjai eltéró gazdasági, társadalmi környezetben nőnek fel, másfajta folyamatok hatnak rájuk, sőt még az adott kor történelmi eseményeit is másként élik meg. Ezek a közös élmények hatással vannak az adott korcsoport értékrendjének alakulására, befolyásolják a munkához, társaikhoz való viszonyukat, viselkedésüket, de még akár személyiségüket is. A folyamatosan változó társadalmi normák éppen ezért állandó ütközési pontot jelentenek a csoportok között. Különösen a nagy történelmi fordulópontok (háborúk, ipari forradalmak) jelentenek töréspontot, de valamilyen új eszköz elterjedése, általánossá váló használata is többször generált már jelentős változásokat. Az elmúlt évszázadban jó néhány ilyen változás történt, az utóbbi néhány évtizedben viszont egyenesen viharos gyorsaságúvá váltak az események. Hatalmas mennyiségü technikai változás, újdonság jelent meg a munkahelyeken és az otthonokban, melyek olyan összetett hatásrendszert generáltak, amihez hasonlóval korábban egyetlen generációnak sem kellett szembenéznie. A folyamatot ráadásul egyetlen eszköz, a számítógép indította el.

Nincs még egy olyan találmány az emberiség történetében, melynek hatása ennyire gyorsan és ilyen széles körben indukált volna változásokat. Az élet minden területét átalakítja a számítógépen alapuló digitális technológia, melynek megismerése, használata folyamatosan új kihívásokat jelent a társadalom tagjai számára. Az új eszközök, szoftverek felgyorsították életritmusunkat, lerövidítették a távolságokat, megváltoztatták kommunikációs szokásainkat. Az internet következtében a világ bármely pontján ugyanazokat az eseményeket, folyamatokat követhetik nyomon a felhasználók, azonos hatások, trendek érvényesülnek, új típusú, globális generáció (McCrindle-Wolfinger, 2009) jött létre.

\section{A GENERÁCIÓS ELMÉLETEK EREDETE}

A generációkat érintő empirikus kutatások elméleti megalapozásánál számos esetben szolgál kiindulópontként a Mannheim Károly 1928-as, Das Problem der Generationen (A generációk problémája) című müvében leírt generációfogalom. Ebben Mannheim a generációt nem szociológiai értelemben vett csoportként, hanem puszta összefüggésként aposztrofálja (Hornyák, 2013). A generációs közösségiesedés kritériumaként három elemet sorol fel:

- kronológiai egyidejüség,

- ugyanazon történelmi-társadalmi térhez és időhöz tartozás, azonos kulturális kontextus,

- részvétel e történelmi-szociális egység közös sorsában, az események ugyanazon tudatrétegből való érzékelése (Mannheim, 2000). 
A generációba tartozásnak tehát nem elégséges feltétele az életkor! Akik egy szempontból, pusztán születésük dátuma alapján alkotnak „közösséget”, azok egy korosztály tagjai, ez az egység viszont nem társadalmi, hanem inkább biológiai fogalomnak tekinthetö.

William Strauss és Neil Howe 1991-ben megjelent müvükben (Strauss-Howe, 1991) Mannheimhez hasonlóan definiálták a generáció fogalmát. Meghatározásuk szerint azokból áll egy társadalmi generáció, akik egy történelmi időn, illetve téren osztoznak, és életük azonos időszakában élnek meg bizonyos történelmi szituációkat. Ez egyfajta kollektív személyiséget biztosít nekik. Ebből következően „létezik valamiféle közös hiedelmük, magatartásformájuk, van közös tapasztalatuk és tulajdonságuk, amit megosztanak egymással, valamint tudatában is vannak közösségükkel (közös viszonyrendszerükkel)" (Voglné et al., 2014, 58.). Straussék azt állítják, hogy az egymást követő generációk értékrendjében, világlátásában és ezekből következően viselkedésében egyfajta ciklikusság figyelhető meg, mely körülbelül egy emberöltő, azaz nyolcvan év elteltével indul ismételten újra. Egy ciklus négy szakaszból áll: felemelkedés (high), ébredés (awakening), kibontakozás (unraveling), krízis (crisis).

A generációk ciklikus elméletét több kritika is érte, mivel azt a benyomást kelti, mintha a generációk évszakok lennének, melyek egyenletesen váltják egymást a korszakokon át. Ez a szimmetrikusság azonban sok társadalmi elemző szerint túl merev valós élethelyzetek vizsgálatára, mivel a világban zajló folyamatok végtelen sok változótól, tényezőtől függnek. Tágabb értelemben azonban igaz az, hogy „minden generáció tényezője saját korszakának és válasza, hatása az öt megelőzőnek" (Zombainé, 2015, 7.).

\section{DIGITÁLIS GENERÁCIÓK}

A hagyományosnak tekinthető generációs elméletek mellett természetesen kialakult több olyan kategorizálás is, mely az egyes csoportok digitális világhoz történő viszonyulásán alapul. Az egyik legismertebb felosztás ezek közül Kulcsár Zsolt 2008-ban megjelent (2014-ben átdolgozott) Az integrativ e-learning felé címü e-bookjában jelent meg.

- 1925-1945 - Veteránok

- 1946-1964 - Bébi-bumm

- 1965-1979 - X generáció

- 1980-1995 - Y generáció

- 1996- $\quad-$ Z generáció (Kulcsár, 2014, 9.)

A felosztásban megjelenő generációk közül a „veteránok” csak idős korukban találkoznak elöször a digitális eszközökkel, ennek következtében általában ne- 
hezen birkóznak meg az új informatikai megoldásokkal, számukra a számítógép használata már önmagában is kihívás. Ez azonban nem jelenti azt, hogy - ha akarnak - ne tudnának ennek megfelelni! A „bébi-bumm” generáció tagjai középkorú felnőttként találkoztak a számítógépekkel, ennek következtében bizonyos szempontból kényszerpályán mozogtak: sokszor munkájuk, munkahelyük megtartása érdekében voltak kénytelenek elsajátítani a számítógépek használatát. Sokan közülük csak alkalmazkodni próbáltak a megváltozott körülményekhez, de az új eszközök, megoldások nem váltak életük szerves részévé, igazán jelentős változást nem generáltak számukra. Az „X generáció” tagjai tinédzserként vagy fiatal felnőttként kerültek kapcsolatba a digitális világgal. Munkájukat jelentősen befolyásolja (sőt nem egyszer alapvetően meghatározza) az új technológia, és azt magánemberként is egyre gyakrabban, egyre szélesebb felhasználási körben alkalmazzák. Az „Y generáció” ${ }^{1}$ viszont már gyermekként találkozott a számítógéppel, sokszor az internettel is, így ezt a generációt nevezhetjük a digitális nemzedék első hullámának. Munkájukba és életvitelükbe szervesen beépült az új technológia, számukra már ezek jelentik a megszokott környezetet. A „Z generáció" tagjai pedig már csak azt a világot ismerik, melyben nemcsak a számítógép, hanem az internet is a mindennapok része, ennek megfelelően a technológiai eszközöket életük első éveitől kezdődően használják. Fiatal koruktól idejük jelentős részét online töltik, nemegyszer ,a közösségi oldalhoz kapcsolódva, kezükben telefonnal alszanak el és kelnek fel" (Zombainé, 2015, 20.).

Mark McCrindle és Emily Wolfinger generációs felosztásában (McCrindleWolfinger, 2009) szerepel még az úgynevezett „Alfa generáció” (a 2010 után születettek) is, akikről viszont még nem sokat tudunk. Ők a jövő reménységei, és egy olyan korban fognak felnőni, amelyet még nem ismerhetünk, csak találgathatjuk, milyen is lesz. Mark McCrindle szerint (idézi Sterbenz, 2014) az alfák lesznek a jövő nagy átalakítói, akik képesek megküzdeni például a környezetszennyezés vagy a globális felmelegedés ártalmaival. A jövőkutatók elképzelései szerint az alfák fognak a legtovább élni az emberiség történetében. Nagyon magasan képzettek és rendkívül felkészültek lesznek, generációjuk valóban komolyan fogja venni a tudás és az élethosszig tartó tanulás jelentőségét (Sterbenz, 2014). Teljes mértékben asszimilálódnak a világhálóba, ennek viszont az az ára, „,hogy ők lesznek a legmagányosabb nemzedék, akik a GOOGLE szemüvegeken keresztül folyamatos hálózati kapcsolatban állnak majd egymással, de egykék lesznek, és egyedül fognak élni is" (Kissné, 2014, 1.).

A digitális nemzedékek közötti generációs különbségek kifejezésére Marc Prensky egy jóval egyszerübb, kétpólusú felosztást alkotott meg, bevezetve a „digitális bennszülött” és „digitális bevándorló” csoportokat (Prensky, 2001). Az

\footnotetext{
${ }^{1}$ Az elnevezésről megoszlanak a vélemények. Van, ahol egyszerűen az X betű követője az ábácében, mások szerint viszont az angol Youth - fiatalság, ifjúság szó rövidítése (Zombainé, 2015).
} 
elnevezéseket alapvetően a diákokkal és a pedagógusokkal kapcsolatban alkotta meg, de széles körben ismertté válva csakhamar általánosságban kezdték azokat használni a gyermekekre és a felnőttekre. A két csoportot az alapján különböztette meg Prensky, hogy életük során mikor találkoztak a digitális technológiával: digitális bennszülötteknek nevezte azokat, akik már infokommunikációs technológiával átszőtt környezetben nőttek fel, akik beleszülettek a technológiák világába, digitális bevándorlóknak pedig azokat nevezte, akik felnőttkorukban ismerkedtek meg ezekkel az eszközökkel, az online léttel.

Az életkoron alapuló generációs elméleteket - ezen belül pedig kiemelten Prensky felosztását - sokan támadták arra hivatkozva, hogy valójában nem egységes, homogén csoportokról van szó, hanem csak ,pszeudo közösségekről” (Pankász, 2016). Számos kutatás bizonyította is, hogy az azonos generációs csoportba tartozó egyének között sokszor nagyobb a különbség, mint a különböző csoportok között. Különösen igaz ez a fiatalabb, iskolás éveiket töltő korosztályokra, akik között például a hagyományos és az ,új millenniumi tanulási stílus” (értve alatta a digitális technológia használatát) egyaránt jelen van (Dede, 2005). Sue Bennett és munkatársai szintén azt állapították meg (Bennet et al., 2008), hogy a sok szempontból egyformának gondolt digitális bennszülöttek közül valójában csak egy szűk réteg rendelkezik igazán magas szintủ digitális készségekkel, a többiek kompetenciája jóval alacsonyabb. Hargittai Eszter empirikus adatokra is támaszkodó munkájában (Hargittai, 2010) szintén arra hívja fel a figyelmet, hogy a digitális bennszülöttek infokommunikációs technológiákhoz kapcsolódó tudása messze nem olyan szintű és magától értetődő, mint ahogy azt sokan gondolják.

Z. Karvalics László ugyancsak elutasítja a születési idő kizárólagos meghatározó voltát, véleménye szerint az ezen alapuló kategorizálás „leszükíti a gondolkodást, elszegényíti a kontextusokat" (Z. Karvalics, 2013, 19.). Úgy véli, hogy még a „bennszülöttek” számára is szükséges a környezet „,beavatási rítusa”, a bevonás a szűkebb és tágabb közösségi integráció felé, hogy képesek legyenek megfelelni az információs társadalom elvárásainak. Számos magyarországi kutatás (például: Török, 2008; Hunya, 2008; Fehér-Hornyák, 2010) is igazolta azt, hogy a digitális bennszülötteknek tekintett tanulók egyáltalán nem alkotnak homogén csoportot, ugyanakkor a pedagógusok egy része bizonyítottan magasabb szintü digitális kompetenciával rendelkezik tanítványainál. A pusztán életkor függvényében történő megkülönböztetés tehát hibás, a digitális öslakosok között vannak alacsony digitális kompetenciát birtoklók, a digitális bevándorlók egy része pedig teljesen asszimilálódott az online világba.

A generációkra alapozott felosztás azért sem lehet helyes, mert végérvényes kategorizálást jelent, pedig a digitális világ is folyamatosan változik, állandóan újjá kell születni, ha nem akarunk lemaradni. Azaz nemcsak a születés időpontja határozza meg az egyén digitális technológiával való találkozását, viszonyát, hanem többek között hat még rá a szociokulturális, illetve gazdasági háttér, a föld- 
rajzi elhelyezkedés és az adott térség fejlettsége is (Lénárd, 2015). Nem kétséges, hogy egy nyomortelep fiatal lakója vagy egy afrikai törzs újszülött gyermeke számára nem adottak azok a feltételek, mint például egy nagyvárosban dolgozó középkorú adminisztrátor vagy egy napilap vidéki tudósítója számára. Kit tekinthetünk akkor közülük digitális bennszülöttnek?

\section{AZ INFORMÁCIÓS TÁRSADALOM TÁRSADALMI CSOPORTJAI}

Az előzőekben igyekeztünk igazolni, hogy a korábban homogénnek gondolt, születési idő alapján kialakított generációs csoportok valójában meglehetősen polarizáltak. Az életkor alapján történő besorolás különösen a digitális bennszülöttek vonatkozásában félrevezető, jobban megfelel a valós helyzetnek, ha a csoportalkotás során a digitális technológiák használatának minőségi mutatóit vesszük figyelembe. Ebből az alapelvből kiindulva készítettük el az információs társadalom tagjainak csoportosítását, mely hat csoportot tartalmaz: digitális remeték, digitális felfedezők, digitális nomádok, digitális vándorok, digitális telepesek, digitális honfoglalók (Buda, 2013).

Digitális remetéknek azokat tekinthetjük, akik egyáltalán nem használják az információs és kommunikációs technológiák eszközeit. Nemcsak az internetre nem csatlakoznak, hanem saját számítógépük, laptopjuk, mobiltelefonjuk sincs, és a munkahelyükön sem használják ezen eszközöket. Az ilyen állapotnak lehetnek egyrészt gazdasági okai (egy [mély]szegénységben élő nyilván nem erre fog költeni), másrészt az elzárkózás lehet tudatos döntés eredménye is. Azonban álljon a háttérben bármi, egyre kevesebben tartoznak majd ebbe a csoportba, az elzárkózást nem lehet már sokáig fenntartani, mert a munkahelyek egyre kisebb hányada tölthető csak be digitális írástudás nélkül, illetve egyre bővül a csak digitálisan intézhető hivatalos ügyek listája.

A digitális felfedezők már elkezdték az ismerkedést az IKT- (információs és kommunikációs technológiák) eszközökkel, de ennek a folyamatnak egyelöre még csak az elején tartanak. Lehet, hogy már birtokolnak egy (egyszerübb) mobiltelefont, esetleg már van otthon számítógépük is, csak az (még) nem csatlakozik az internetre, vagy lehet, hogy kizárólag munkahelyükön használnak (kényszerűségből) számítógépet. Egy biztos, ők az első lépéseket már megtették, de még csak az út elején járnak.

A digitális nomádok már egyértelmúen számítógép- és internethasználók, de az alkalmazás intenzitása még meglehetősen alacsony, számos elemben mutatkozik meg bizonytalanságuk, helykeresésük (Buda, 2011). Elsősorban fogyasztják az információkat, azok „termelésében” nem vagy alig vesznek részt, az internet vonatkozásában ők egyértelmủen web 1.0-ás felhasználók. Ha a nomádoknak valamilyen információra van szükségük, akkor először nem feltétlenül az interneten 
kezdenek kutatni, de ha igen, akkor ott elsősorban a szöveges információkat keresik, videókat, filmeket nem nagyon szoktak letölteni. A számítógép használata során ragaszkodnak a megszokott programokhoz, internetes helyekhez, ezeket nem párhuzamosan, hanem egymás után használják. Digitális kommunikációjuk alacsony intenzitású, közösségi oldalaknak nem tagjai, vagy ha igen, akkor csak ritkán lépnek be oda.

A digitális telepesek felelnek meg leginkább napjaink kihívásainak, ők az információs társadalom ideális polgárai. Nemcsak használnak digitális tartalmakat, hanem elö is állítanak ilyeneket, szöveges, képi vagy multimédiás formában egyaránt. Elsősorban digitálisan kommunikálnak, a közösségi oldalakat, levelezési csoportokat valódi kapcsolatápolásra, szociálisháló-építésre és nem tartalmatlan „ismerős gyüjtésre” használják. Számos más tevékenységet is (például: számlák befizetése, adóbevallás, szállásfoglalás) az internet segítségével valósítanak meg. Véleményünk szerint csak azokat tekinthetjük igazi digitális telepeseknek, akikre a következő jellemzők mindegyike ráillik:

- legfontosabb információforrásuk az internet,

- web 2.0-ás felhasználók,

- multimédiás elemekre épülő befogadás,

- nagymértékủ digitális kommunikáció,

- intenzív jelenlét különböző közösségi oldalon, oldalakon,

- gyors alkalmazkodás az új programokhoz, technikai fejlesztésekhez,

- digitális ügyintézés,

- multitasking.

A digitális nomádok és a digitális telepesek között helyezkednek el a digitális vándorok. Ök egyes jellemzőikben már meghaladják a nomádok sajátosságait, de összességében még nem érik el a telepesek szintjét. Lehet például, hogy elsősorban az internetről gyüjtik az információkat, ugyanakkor viszont a közösségi oldalakon alig jelennek meg, vagy éppen könnyedén elsajátítják új telefonjuk kezelését, de az internetes kommunikációjuk még alacsony szintü. A telepesek nyolc jellemzője közül legalább egy még hiányzik, de ez lehet akár tudatos döntés következménye is, hiszen például az adatkezelés biztonságával kapcsolatos fenntartások sokakat visszatartanak a közösségi oldalak használatától.

A legmagasabb szinten digitalizálódott csoport, a digitális honfoglalók számára gyakorlatilag az internet jelenti az egyetlen információforrást, éppen ezért sokszor elvonási tünetek jelentkeznek náluk, ha el kell szakadniuk a hálózattól. Laptop, iPad vagy mobiltelefon segítségével szinte állandóan online vannak, kommunikációjuk döntően digitális, akadnak olyan társaik, akikkel nemegyszer kizárólag digitális alteregójukon, azaz avatarjukon keresztül kommunikálnak. Annyira a digitális világ büvkörében élnek, hogy sokszor meg sem értik a digitális felfedezők vagy nomádok problémáit. 


\section{DIGITÁLIS ÁLLAMPOLGÁRSÁG}

A digitális bennszülött és digitális bevándorló elnevezések elavultságát maga Marc Prensky, az elnevezések megalkotója is elismeri 2009-es munkájában (Prensky, 2009). Sőt helyettük egy új megnevezést, a „homo sapiens digitalis” használatát javasolja. Véleménye szerint ennek az új embertípusnak nemcsak okosabban, hanem bölcsebben is kellene használnia a digitális technológiát, mivel a technológia önmagában nem helyettesíti az intuíciót, a helyes ítéletet, a problémamegoldó képességet, és nem ad világos erkölcsi iránytűt sem. Éppen ezért „a homo sapiens digitalis" két kulcsfontosságú tekintetben különbözik a mai embertől. Egyrészt a digitális fejlődést az emberi élet szerves, természetes részeként fogadja el, másrészt digitális bölcsességgel is bír.

Az elmúlt néhány évben egy olyan új megközelítés is napvilágot látott, mely szerint a digitális világba belépő, ott különböző módon és mélységben aktivizálódó egyének az úgynevezett „digitális állampolgárság” keretei között végzik tevékenységeiket (Ohler, 2010; Ribble, 2011; Ollé, 2012). A fogalom kétféle módon is értelmezhetö. Az egyik megközelítés az online végzett tevékenységre épül, azokat vizsgálja, és elvárásokat is megfogalmaz ezzel kapcsolatban. Az így gondolkodók (legismertebb közülük Jason Ohler) szerint a digitális állampolgárság nem nemzedékekhez köthető sajátosság, hanem tanulható, tanítható jellemzöje az egyénnek. A digitális állampolgárnak ugyanis úgy kell tevékenykednie az interneten, hogy az a közösség számára is értékes, hasznos legyen. Ez a tudás azonban nem velünk született, hanem el kell sajátítanunk, sőt folyamatosan alakítanunk, fejlesztenünk kell az aktuális elvárásoknak megfelelően. Ügyelni kell közben arra, hogy nehogy kettős világ jöjjön létre körülöttünk, külön létezzen számunkra a hagyományos, természetes (offline) környezet, és ettől elkülönülve a digitális (online) világ, ahol nem feltétlenül érvényesülnek a megszokott szabályok, és megváltozik az értékrend is. El kell érni, hogy a digitális világ a valós környezettel együtt egy egységet alkosson.

A másik értelmezés társadalomelméleti irányból közelít a digitális állampolgársághoz. Egyik jeles képviselőjük, Karen Mossberger és munkatársai úgy gondolják (Mossberger et al., 2008), hogy a digitális jelző hozzáadásával a hagyományos állampolgári tevékenységek jelentősen átalakulnak, kiterjesztésre kerülnek annak köszönhetően, hogy az internet által a fizikai közösségek globális közösségekké alakulnak át. Ennek megfelelően, modelljük szerint „,a digitális állampolgárság nem más, mint az online társadalomban való részvétel képessége, a napi szintü, szabályos és hatékony internethasználat" (Ollé, 2012, 1.). Az egyik balti államban, Észtországban már minden felnőtt rendelkezik digitális állampolgársággal, és egy e-személyivel is, mellyel bármilyen hivatalos ügyet néhány kattintással el tud intézni a világ bármely pontjáról. Ez azonban azt jelenti, hogy ha valaki nem vagy nem rendszeresen jut internethez, az gátja lehet a digitális állampolgár- 
rá válásának, illetve akadályozhatja digitális fejlődését. Így az internethasználat hiánya, sőt már a használat eltérő szintje is jelentős társadalmi különbségeket generál, melyek révén, végső soron új, korábban nem ismert problémákkal kell társadalmi szinten szembenézni.

\section{IRODALOM}

Bennett, S. J. - Maton, K. A. - Kervin, L. (2008): The „Digital Natives Debate”: A Critical Review of the Evidence. British Journal of Educational Technology, 39, 5, 775-786. https://bit. ly/2DuXjSE

Buda A. (2011): Telepesek és nomádok. In: Cser L. - Herdon M. (szerk.): Informatika a felsőoktatásban. Debrecen, 913-918.

Buda A. (2013): Pedagógusok az információs társadalomban. In: Lévai D. - Szekszárdi J. (szerk.): Digitális pedagógus konferencia. Konferenciakötet. Budapest: ELTE. 9-16. http://bit.ly/1r2X6XJ (2014. 01. 11.)

Dede, C. (2005): Planning for Neomillennial Learning Styles: Implications for Investments in Faculty and Technology. In: Oblinger, D. - Oblinger, J. (eds.): Educating the Net Generation. Boulder, CO: EDUCAUSE, 15.1-15.22, https://bit.ly/2BernjO (2017. 05. 03.)

Fehér P. - Hornyák J. (2010): Netgeneráció 2010: Digitális bennszülöttek. In: Oktatás plusz 2010. HVG Online Szakmai kiadvány. 12, Budapest: HVG Online Zrt., 114-118.

Hargittai, E. (2010): Digital Na(t)ives? Variation in Internet Skills and Uses among Members of the „Net Generation”. Sociological Inquiry, 80, 1, 92-113. DOI: 10.1111/j.1475-682X.2009.00317.x (2016. 12. 14.)

Hornyák P. I. (2013): Generáció a fogalomtörténet mérlegén. Megjegyzések Koselleck generációra vonatkozó gondolataihoz. Nagyerdei Almanach, 2, 96-126. http://bit.ly/2yeDYTW (2016. 12. 16.)

Hunya M. (2008): A számitógéppel segitett tanulás. Budapest: ELTE

Kissné András K. (2014): Generációk, munkaerőpiac és a motiváció kérdései a 21. században. http://bit.ly/2woXDf0 (2015. 05. 26.)

Kulcsár Zs. (2014): Az integrativ e-learning felé. http://bit.ly/2pa8mYF (2016. 07. 12.)

Lénárd A. (2015): A digitális kor gyermekei. Gyermeknevelés, 3, 1, 74-83. https://bit.ly/2Bf8kFY

Mannheim K. (2000): A nemzedékek problémája. In: Mannheim Károly: Tudásszociológiai tanulmányok. Budapest: Osiris, 201-254.

McCrindle, M. - Wolfinger, E. (2009): The ABC of XYZ: Understanding the Global Generations. Sidney: University of New South Wales Press, http://bit.ly/2FAEeMQ (2017. 01. 17.)

Mossberger, K. - Tolbert, C. J. - McNeal, R. S. (2008): Digital Citizenship. The Internet, Society, and Participation. Cambridge, Massachusetts-London: The MIT Press

Ohler, J. B. (2010): Digital Community, Digital Citizen. London: Corwin

Ollé J. (2012): A digitális állampolgárság értelmezése és fejlesztési lehetőségei. Oktatás-Informatika, 1-2. http://bit.ly/15BA4h1 (2013. 10. 20.)

Pankász B. (2016): Online oktatási környezet és IKT tényezök összehasonlitó vizsgálata a felsőoktatásban. Pécs: Pécsi Tudományegyetem

Prensky, M. (2001): Digital Natives, Digital Immigrants In: On the Horizon. (MCB University Press) 9, 5, October, 1-6. DOI: 10.1108/10748120110424816, https://bit.ly/2ySL1ib

Prensky, M. (2009): H. sapiens digital: From Digital Immigrants and Digital Natives To Digital Wisdom. Innovate, 5 , 3, http://bit.ly/2xE1qZL (2009. 02. 04.) 
Ribble, M. (2011): Digital Citizenship in Schools. Eugene, Oregon-Arlington, Virginia: International Society for Technology in Education, https://amzn.to/2BdgZc8

Sterbenz, C. (2014): Generation Alpha Is Coming and It Will Change the World Forever. Business Insider. http://read.bi/1QCiOPa (2017. 03. 11.)

Strauss, W. - Howe, N. (1991): Generations: The History of America's Future, 1584 to 2069. New York: Harper Perennial, William Morrow and Company

Török B. (2008): Az információs és kommunikációs technológiák iskolai integrációja-IKT-metria méröeszköz. PhD-értekezés. Budapest: ELTE, https://bit.ly/2Bd8YUk

Voglné Nagy Zs. - Lippai E. - Nagy V. (2014): Digitális bevándorlók és bennszülöttek - a digitális tudásmegosztás és interaktivitás lehetőségei. Iskolakultúra, 1, 57-63. https://bit.ly/2QStTBB

Z. Karvalics L. (2013): Mangalány mondja: közeledik a „digitális beavatottak” ideje. In: Lévai D. (szerk.): Digitális nemzedék konferencia 2013. Konferenciakötet. Budapest: ELTE, 19-23. http://bit.ly/1KxL575 (2017. 05. 18.)

Zombainé Tarnótzky K. (2015): Generációk összehasonlitása, különös tekintettel a Z generáció és tanáraik között fellelhetö különbségekre. Budapest: Budapesti Gazdasági Főiskola, https:// bit.ly/2Drldvw 